\title{
Degradable polyethylenimine derivate coupled to a bifunctional peptide RI 3 as a new gene-delivery vector
}

This article was published in the following Dove Press journal:

International Journal of Nanomedicine

28 February 2012

Number of times this article has been viewed

\author{
Kehai Liu',2,* \\ Xiaoyu Wangl,* \\ Wei Fan' \\ Qing Zhu ${ }^{2}$ \\ Jingya Yang² \\ Jing $\mathrm{Gao}^{3}$ \\ Shen Gao'
}

'Department of Pharmaceutics, Shanghai Hospital, Second Military Medical University, ${ }^{2}$ Department of Biopharmaceutics, School of Food Science and Technology, Shanghai Ocean University, ${ }^{3}$ Department of Pharmaceutics, School of Pharmacy, Second Military Medical University, Shanghai, People's Republic of China

*The first two authors contributed equally to this work
Correspondence: Shen Gao Department of Pharmaceutics, Shanghai Hospital, Second Military Medical University, Shanghai,

People's Republic of China

Tel +862181873715

Fax +86 2181873724

Email khliu@shou.edu.cn
Background: To solve the efficiency versus cytotoxicity and tumor-targeting problems of polyethylenimine (PEI) used as a nonviral gene delivery vector, a degradable PEI derivate coupled to a bifunctional peptide R13 was developed.

Methods: First, we synthesized a degradable PEI derivate by crosslinking low-molecular-weight PEI with pluronic P123, then used tumor-targeting peptide arginine-glycine-aspartate-cysteine (RGDC), in conjunction with the cell-penetrating peptide Tat (49-57), to yield a bifunctional peptide RGDC-Tat (49-57) named R13, which can improve cell selection and increase cellular uptake, and, lastly, adopted R13 to modify the PEI derivates so as to prepare a new polymeric gene vector (P123-PEI-R13). The new gene vector was characterized in terms of its chemical structure and biophysical parameters. We also investigated the specificity, cytotoxicity, and gene transfection efficiency of this vector in $\alpha v \beta 3$-positive human cervical carcinoma Hela cells and murine melanoma B16 cells in vitro.

Results: The vector showed controlled degradation, strong targeting specificity to $\alpha v \beta 3$ receptor, and noncytotoxicity in Hela cells and B16 cells at higher doses, in contrast to PEI $25 \mathrm{KDa}$. The particle size of P123-PEI-R13/DNA complexes was around 100-250 nm, with proper zeta potential. The nanoparticles can protect plasmid DNA from being digested by DNase I at a concentration of $6 \mathrm{U}$ DNase I/ $\mu \mathrm{g}$ DNA. The nanoparticles were resistant to dissociation induced by $50 \%$ fetal bovine serum and $600 \mu \mathrm{g} / \mathrm{mL}$ sodium heparin. P123-PEI-R13 also revealed higher transfection efficiency in two cell lines as compared with PEI $25 \mathrm{KDa}$.

Conclusion: P123-PEI-R13 is a potential candidate as a safe and efficient gene-delivery carrier for gene therapy.

Keywords: nonviral gene vector, polyethylenimine, P123, $\alpha \mathrm{v} \beta 3$, cell-penetrating peptides

\section{Introduction}

Cancer is a scourge of the human race. Its classical treatments such as surgery, chemotherapy, and radiotherapy are still insufficiently effective in many cases; thus, new anticancer strategies are urgently required. ${ }^{1}$ Gene therapy provides a promising tool to eradicate this disease by treating it at its source. The key to gene therapy is finding an ideal gene-delivery vector. Delivery of nucleic acids into cells using cationic polymers has recently attracted remarkable interest in the field of nonviral gene therapy, due to their structural diversity, easy production, nonimmunogenicity, and safety. ${ }^{2}$ One of the most effective and widely studied synthetic nonviral gene-delivery vectors is the polycation polyethylenimine (PEI), which has recently been employed for the design of DNA-delivery vehicles. By adding this cationic polymer to DNA, the condensed complexes can be spontaneously formed through electrostatic interactions, resulting in efficient transport of intact DNA into the nucleus. ${ }^{3-5}$ Gene delivery using PEI involves 
condensation of DNA into compact particles, uptake into the cells, release from the endosomal compartment into the cytoplasm, and uptake of the DNA into the nucleus. The high transfection efficiency of PEI/DNA complexes should be ascribed to the "proton sponge" effect of PEI. ${ }^{6,7}$ However, polyplexes of PEI/DNA have shown two outstanding problems. First of all, long PEI chains are highly effective in gene transfection but are cytotoxic. Conversely, short PEI chains display lower cytotoxicity but lower efficiency. ${ }^{8}$ The major drawback with gene delivery using PEI is the lack of satisfactory specificity toward tumor cells, because there is no binding selectivity between the positively charged polycation and the negatively charged body cells. ${ }^{9}$

Pluronic block copolymers, which consist of hydrophilic ethylene oxide (EO) and hydrophobic propylene oxide (PO) blocks arranged in a basic A-B-A structure (EO x -PO y -EO $\mathrm{x})$, are amphiphilic molecules that can be used as structural elements of the polycation-based gene-delivery systems. ${ }^{10}$ Kabanov et $\mathrm{al}^{10-13}$ previously reported that pluronic can enhance cell interactions, DNA transport, and transgene expression, and possesses the unique ability to be incorporated into cell membranes as a result of the presence of the hydrophobic poly-PO chain. In contrast, hydrophilic EO chains do not interact with lipid membranes but can be used to prevent binding of other polymers with the membranes. ${ }^{10}$ The systems are stabilized in dispersion by the EO corona in a manner similar to regular pluronic micelles. The micelles of these copolymers are sufficiently potent in the ability to bind cellular membrane, and a relatively high concentration of micelles can be reached in solution. ${ }^{14}$ Among these copolymers, pluronic notation P123 with formula EO20-PO70EO20 exhibits higher stability in terms of critical micelle concentration. ${ }^{15}$ In this paper we link low-molecular-weight PEI (LMW PEI) with P123 by chemical crosslinking to obtain cladodromous or cancellated PEI derivates with high molecular weight, which can guarantee higher transfection efficiency and degrade into lower-cytotoxic LMW PEI because of crosslinked chemical bond cleavage by hydrolysis after uptake into the cells. Hence, this makes it possible to greatly reduce the cytotoxicity of PEI on the premise of ensuring higher transfection efficiency and thereby solves the "catch 22" problem of efficiency versus cytotoxicity.

Receptor-mediated tumor targeting is another increasingly important research field of nonviral gene-delivery systems. Integrins are a family of transmembrane glycoproteins with relatively small cytoplasmic domains. They consist of two subunits, $\alpha$ and $\beta$. Generally, as receptors, an individual integrin may recognize several distinct proteins. Among the integrins, the $\alpha v \beta 3$ receptor is involved in tumor cell migration and angiogenesis. The $\alpha v \beta 3$ receptors are highly expressed on tumor cells and tumor angiogenic blood vessels, whereas they are not detectable on quiescent blood vessels. Thus, the $\alpha v \beta 3$ integrin participates in tumor metastasis and tumor-related angiogenesis. ${ }^{16}$ The highly selective expression of $\alpha v \beta 3$ integrin in the neovascular tissue and various tumors allows its use as a suitable target. Arginine-glycineaspartate (RGD) peptide is a key binding moiety that has been shown to bind specifically to $\alpha v \beta 3$ integrin receptors. ${ }^{17}$ Cell-penetrating peptides (CPPs) are 7-30 amino acid long peptides capable of translocating various macromolecules across the plasma membrane and targeting to the cell nucleus. CPPs have been applied to gene delivery. Kilk et al ${ }^{18}$ demonstrated that CPP transportan 10 (TP10) could enhance PEImediated transfection at relatively low concentrations and help to develop future gene-delivery systems with reduced toxicity. The HIV Tat-derived peptide is a small basic peptide for successfully delivering a large variety of cargoes into cells such as nanoparticles, proteins, and nucleic acids. The transduction domain or region conveying CPPs appears to be confined to a small stretch of basic amino acids with the sequence RKKRRQRRR and is known as Tat (49-57). 19,20 Therefore, we have used a linear RGD peptide, RGDC, in conjunction with Tat (49-57) to yield a new chimeric peptide, RGDC-Tat (49-57), named R13. The bifunctional R13 can target to $\alpha v \beta 3$ receptors expressed abundantly on tumor cells and carry cargo molecules inside the cells. Adopting R13 to modify PEI derivates can improve cell selection, promote cargo transport, and enhance transfection efficiency.

Above all, in this work, we first linked LMW PEI with P123 to obtain degradable PEI derivates with high molecular weight, then used tumor-targeting peptide RGD, in conjunction with the CPP Tat (49-57) to yield a bifunctional peptide R13, and, lastly, adopted R13 to modify the PEI derivates so as to prepare a new nonviral gene delivery vector (P123-PEI-R13). The new gene vector was characterized in terms of its chemical structure and biophysical parameters. We also investigated the specificity, cytotoxicity, and gene transfection efficiency of this vector in $\alpha v \beta 3$-positive human cervical carcinoma Hela cells and murine melanoma B16 cells in vitro. The purpose of the present study was to reduce cytotoxicity of PEI, improve its tumor targeting, and increase cellular uptake of genes, enhancing the therapeutic effect of gene therapy on cancer.

\section{Materials and methods Materials}

Branched PEI (MW 2000), fluorescein isothiocyanate (FITC), N-succinimidyl-4-(N-maleimido-methyl) cyclohexane-1-carboxylate (SMCC), horseradish peroxidase 
(HRP), heparin, and 3-(4, 5-dimethylthiazol-2-yl)-2, 5-diphenyl tetrazolium bromide (MTT) were obtained from Sigma-Aldrich (St Louis, MO). P123 was kindly provided by BASF Corporation (Mount Olive, NJ). DNase I was purchased from the Worthington Company (Lakewood, NJ). RPMI 1640 culture medium and fetal bovine serum (FBS) were purchased from Invitrogen (Carlsbad, CA). Luciferase assay system for in vitro transfection assay and pGL-3 control vector with SC-40 promoter and enhancer encoding firefly (Photinus pyralis) luciferase were obtained by Promega (Madison, WI). The plasmid encoding the enhanced green fluorescent protein (pEGFP-N2) was kindly provided by the Institute of Life Science and Technology of Tongji University (Shanghai, People's Republic of China). The plasmids were amplified using Escherichia coli DH5 $\alpha$ and prepared using the Qiagen End-free Plasmid Mega Kit (Qiagen GmbH, Hilden, Germany). The purity of the purified and concentrated DNA was determined by measuring its ultraviolet absorbance at $260 \mathrm{~nm}$ and $280 \mathrm{~nm}$ respectively. The oligopeptide Arg-Gly-AspCys-Arg-Lys-Lys-Arg-Arg-Gln-Arg-Arg-Arg (R13, MW 1771.10 Da) was synthesized by GL Biochem (Shanghai, China), and the amino acid sequence was confirmed by mass spectroscopy.

\section{Binding of R I 3 to integrin receptor}

Integrin $\alpha v \beta 3$ receptors are highly expressed on Hela cells and B16 cells and almost not expressed on MCF-7 cells. Three kinds of cells were cultivated under standard conditions at $37^{\circ} \mathrm{C}$ in a humidified $95 \%$ air $/ 5 \% \mathrm{CO}_{2}$ atmosphere in RPMI 1640 in the presence of $10 \%$ FBS. Before the experiment, the cells were trypsinized and centrifuged to remove culture medium, and then $1 \%$ bovine serum albumin solution was added to block the protein-binding site. After incubation for 20 minutes, the cells were centrifuged to remove the bovine serum albumin solution, resuspended, and cultivated with FITC-conjugated R13 (FITC-R13) for 60 minutes at $37^{\circ} \mathrm{C}$ (approximately $1 \times 10^{6}$ cells and 0.5 nmol FITC-R13 in $1 \mathrm{~mL}$ phosphate-buffered saline [PBS]). The cells were washed with $3 \mathrm{~mL}$ of $0.01 \mathrm{M}$ PBS four times and resuspended in PBS to determine the binding affinity of R13 to integrin receptor using flow cytometry (BD FaCSAria; BD, NJ).

\section{Synthesis of PI23-PEI-RI3 \\ Synthesis of PI23-PEI}

Activated P123 should be obtained first in order to prepare P123-PEI. P123 (0.6 mmol) was dried by coevaporation with anhydrous toluene in a vacuum at $50^{\circ} \mathrm{C}$, then dissolved in toluene/dichloromethane $(3: 1,40 \mathrm{~mL})$ and treated with bis-(trichloromethyl)-carbonate $(0.356 \mathrm{~g}$, $1.2 \mathrm{mmol}$ ) overnight. After the solution was evaporated to dryness under a vacuum, the residue was redissolved in toluene/dechloromethane $(2: 1,30 \mathrm{~mL})$ and treated with solid N-hydroxysuccinimide $(0.240 \mathrm{~g}, 2.0 \mathrm{mmol})$, followed by anhydrous triethylamine $(0.28 \mathrm{~mL}, 2.0 \mathrm{mmol})$. After 4 hours of stirring, the solution was filtered and evaporated to dryness. The product was purified on a silica gel column using stepwise elution with trichloromethane methanol $(10 \%-15 \%, \mathrm{v} / \mathrm{v})$ mixtures.

LMW PEI (0.20 g, $0.10 \mathrm{mmol})$ was dissolved in $10 \mathrm{~mL}$ anhydrous dichloromethane as Solution $\mathrm{A}$, and the predetermined amount of activated P123 (0.01 mmol) was dissolved in $10 \mathrm{~mL}$ anhydrous ethanol as Solution B. Then, Solution A and Solution B were slowly added to a base solution of $10 \mathrm{~mL}$ anhydrous dichloromethane with constant stirring. The reaction mixture was left overnight at room temperature. After completion of reaction, the conjugate was dialyzed using Spectra/Por 1 dialysis membrane (Spectrum, CA) against distilled water at $4^{\circ} \mathrm{C}$ for 2 days and then lyophilized.

\section{Conjugation of PI23-PEI with RI3}

P123-PEI was conjugated with R13 using SMCC as crosslinker. After the appropriate amount of SMCC solution (3.33 $\mathrm{mg} / \mathrm{mL}$ in dimethyl sulfoxide) was added dropwise to P123-PEI solution ( $9 \mathrm{mg} / \mathrm{mL}$ in $0.1 \mathrm{M}$ PBS $)$ at a molar ratio of 10:1, 5:1, and $2: 1$, the reaction mixture was incubated for 30 minutes at room temperature with gentle shaking. The excess nonreacted crosslinker was removed by gel chromatography (Sephadex G-25; Pharmacia, Milton Keynes, UK). Thus, $N$-hydroxysuccinimide (NHS) eaters of SMCC have reacted with primary amines of P123-PEI to form amide bonds and produce the maleimide-activated P123PEI. Then, R13 (10 mg/mL in 0.1M PBS) was reacted with the maleimide-activated P123-PEI at a molar ratio of 10:1, $5: 1$, and $2: 1$. The reaction mixture was stirred in the dark overnight at $4^{\circ} \mathrm{C}$ and then lyophilized after the nonreacted $\mathrm{R} 13$ was removed by ultrafiltration with Amicon Ultra-4 centrifugal filter devices (Millipore, Billerica, MA). Then, three types of cationic polymer were obtained and named P123-PEI-R13-h, P123-PEI-R13-m, and P123-PEI-R13-1, respectively.

\section{Characterizations of PI23-PEI-R I3 (NMR, GPC)}

A total of $10 \mathrm{mg}$ of P123-PEI and P123-PEI-R13 was dissolved in $0.6 \mathrm{~mL}$ of deuterium oxide $\left(\mathrm{D}_{2} \mathrm{O}\right)$ in a nuclear 
magnetic resonance (NMR) tube, and the ${ }^{1} \mathrm{H}$ NMR spectra were recorded using a Varian $300 \mathrm{MHz}$ spectrometer at room temperature.

The molecular weight and its distribution of the polymers were measured by gel permeation chromatography with multiangle laser light scattering (GPC-MALLS) (LC-20 AD; Shimadzu, Kyoto, Japan) (690 nm laser wavelength) using TSK-GEL G5000PW ${ }_{\mathrm{XL}}$ column (temperature $40^{\circ} \mathrm{C}$ ) operated at a flow rate of $0.4 \mathrm{~mL} /$ minute. Ammonium acetate $(0.2 \mathrm{M})$ was used as a mobile phase.

\section{Degradation of PI23-PEI-R I 3}

Degradation of P123-PEI-R13 was estimated by the measurement of molecular weight. Of the polymers, $0.5 \mathrm{~g}$ was dissolved in $10 \mathrm{~mL}$ of PBS $(0.1 \mathrm{M}, \mathrm{pH}=7.4)$ and incubated at $37^{\circ} \mathrm{C}$ with shaking at $100 \mathrm{rpm}$. After incubation for different lengths of time, solutions of the polymers were lyophilized and the molecular weights of lyophilized samples were measured by GPC-MALLS with $690 \mathrm{~nm}$ laser wavelength.

\section{Preparation of PI23-PEI-R I3/DNA complexes}

Charge ratio (w/w) of P123-PEI-R13/DNA complex was expressed as the ratio of the weight of P123-PEI-R13 and DNA. Complexes were induced to self-assemble by mixing DNA solution with polymer solution (0.1M PBS, $\mathrm{pH}=7.4$ ) at a desired charge ratio. The complexes were allowed to stand at room temperature for 30 minutes.

\section{Measurement of particle size and zeta potential}

The sizes and zeta potential of polymer/DNA complexes in PBS buffer at room temperature were measured using an electrophoretic light-scattering spectrophotometer (Zetasizer Nano ZS90, MAN0317 Issue 5.0; Malvern Instruments, Malvern, UK), with $90^{\circ}$ scattering angles. The complexes were prepared at desired w/w ratios and incubated at room temperature for 30 minutes before the sizes and zeta potential measurements were carried out. All the experiments were performed in triplicate.

\section{Agarose gel retardation assay}

After preparation of polymer/DNA complexes, $10 \mu \mathrm{L}$ of the complex solution (250 ng of plasmid DNA) was added to $1 \mu \mathrm{L}$ of a $10 \times$ loading buffer. The sample was electrophoresed on $1 \%(\mathrm{w} / \mathrm{v})$ agarose gel for 40 minutes at $120 \mathrm{~V}$. The gel was stained with ethidium bromide $(0.5 \mu \mathrm{g} / \mathrm{mL})$ for about 20 minutes at room temperature and illuminated on an ultraviolet illuminator to show the location of the DNA.

\section{Resistance to DNase I digestion}

Different amounts of DNase I were added to $10 \mu \mathrm{L}$ of the complex solution (250 ng of plasmid DNA) in $0.5 \mathrm{~mL}$ Eppendorf tubes and incubated at $37^{\circ} \mathrm{C}$ for 15 minutes. Then, $2 \mu \mathrm{L}$ of $250 \mathrm{mM}$ EDTA solution was added to each tube and incubated at room temperature for 10 minutes to inactivate DNase I. Next, $10 \mu \mathrm{L}$ of $2 \mathrm{mg} / \mathrm{mL}$ sodium heparin was added to each tube and incubated at room temperature for 2 hours to dissociate the complex completely. After that, the electrophoresis was performed to evaluate the resistance of P123-PEI-R13 to DNase I digestion.

\section{Resistance to serum and heparin}

A total of $10 \mu \mathrm{L}$ per tube of the complex solution (250 ng of plasmid DNA) was added to $0.5 \mathrm{~mL}$ Eppendorf tubes. Different volumes of FBS were added and incubated at $37^{\circ} \mathrm{C}$ for 60 minutes. Similarly, different concentrations of $2 \mu \mathrm{L}$ sodium heparin solution were added to $0.5 \mathrm{~mL}$ tubes containing $10 \mu \mathrm{L}$ of the complex solution and incubated at $37^{\circ} \mathrm{C}$ for 30 minutes. Then, the electrophoresis was performed to determine the sensitivity of the polymer/DNA complex to serum and heparin.

\section{Cytotoxicity assay}

The cytotoxicity of the polymers on the B16 and Hela cells was measured using the MTT assay. B16 and Hela cells were seeded at a density of 5000 cells per well in $200 \mu \mathrm{L}$ of growth medium in 96-well plates and incubated for 24 hours to reach $80 \%$ confluence. Then, the culture medium was replaced with fresh serum-free mediums containing serial dilutions of P123-PEI-R13, PEI $2 \mathrm{kDa}$, and PEI $25 \mathrm{kDa}$ at various concentrations $(4 \mu \mathrm{g} / \mathrm{mL}$, $8 \mu \mathrm{g} / \mathrm{mL}, 16 \mu \mathrm{g} / \mathrm{mL}, 24 \mu \mathrm{g} / \mathrm{mL}, 32 \mu \mathrm{g} / \mathrm{mL}$, and $48 \mu \mathrm{g} / \mathrm{mL})$. The cells were incubated for another 24 hours before the medium was replaced with $180 \mu \mathrm{L}$ of fresh growth medium and $20 \mu \mathrm{L}$ MTT $(5 \mathrm{mg} / \mathrm{mL})$ was added. After 4 hours of incubation, unreacted dye was removed by aspiration and $150 \mu \mathrm{L}$ of dimethyl sulfoxide was added as a solvent for formazan crystals. The absorbance value at $570 \mathrm{~nm}$ was determined using an ELISA plate reader (Model 680; BioRad, Hercules, CA). Cell viability was calculated from 
these data. The cell viability (\%) was calculated according to the following equation:

Cell viability $(\%)=\left(A_{\text {test }} / A_{\text {control }}\right) \times 100$ (mean \pm standard deviation, $\mathrm{n}=6$ )

where $A_{\text {test }}$ is the PEI-P123-R13 or PEI-treated cells and $A_{\text {control }}$ is the absorbance of the untreated cells.

\section{In vitro gene transfection}

We examined the ability of P123-PEI-R13 to transfect Hela cells and B16 cells using the plasmid pEGFP-N2 and pGL3control. The cells were seeded in 24-well plates at a density of $1 \times 10^{5}$ cells per well in RPMI 1640 medium containing $10 \%$ FBS, $100 \mathrm{U} / \mathrm{mL}$ penicillin, and $100 \mu \mathrm{g} / \mathrm{mL}$ streptomycin, and incubated for 18-24 hours to reach $80 \%$ confluence. Before transfection, the medium was replaced with $450 \mu \mathrm{L}$ fresh RPMI 1640 supplemented with 10\% FBS. Then, $50 \mu \mathrm{L}$ of the polymer/DNA complex solution containing $0.8 \mu \mathrm{g}$ of pDNA at various weight ratios ranging from 2 to 30 were added to 24-well plates and incubated for 4 hours at $37^{\circ} \mathrm{C}$ in a $5 \% \mathrm{CO}_{2}$ atmosphere. Then, the polymer concentration was calculated according to the $\mathrm{w} / \mathrm{w}$ ratio, and the final volume of culture medium per well ranged from $3.2 \mu \mathrm{g} / \mathrm{mL}$ to $48 \mu \mathrm{g} / \mathrm{mL}$. After exchanging with a fresh medium with $10 \%$ FBS, cells were further incubated for 48 hours. After transfection for 48 hours, inverted fluorescent microscope (AE-31, Motic Corporation, Wetzlar, Germany) was used to observe the EGFP expression

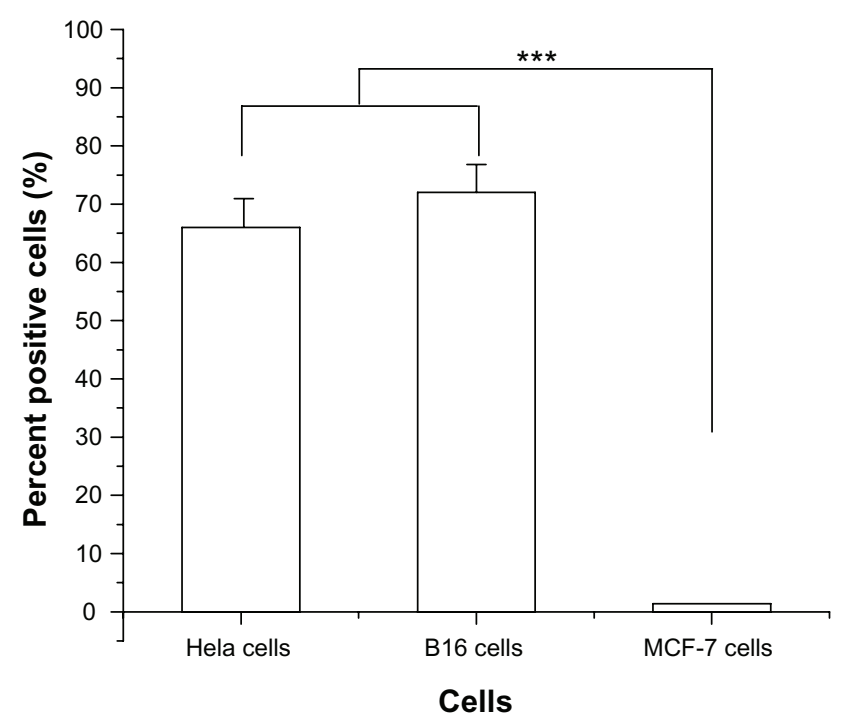

Figure I Percentage of binding of fluorescein isothiocyanate-conjugated R-13 to different cells by flow cytometry analysis.

Notes: Each data point represents the mean \pm standard deviation. $n=3$, $* * * P<0.001$. of the polyplexes in Hela cells and B16 cells. Then, the cells were trypsinized, centrifuged to remove culture medium, and resuspended in PBS to determine transfection efficiency using flow cytometry (BD FaCSAria). The data analysis was performed using the CellQuest software (Becton Dickinson, Franklin Lakes, NJ).

The luciferase assay was carried out according to the manufacturer's instructions (Promega, Madison, WI). The growth medium was removed, and the cells were shaken for 30 minutes at room temperature in $200 \mu \mathrm{L}$ of cell culture lysis reagent (CCLR). Luciferase activity was measured with a luminometer (Turner Designs Luminometer Model TD-20/20; Promega). The relative light units were normalized against protein concentration in the cell extracts, which was measured using a BCA protein assay kit (Pierce, Rockford, IL).

\section{Results and discussion Binding of FITC-R I 3 to $\alpha v \beta 3$-positive cells}

In order to evaluate the specificity of $\mathrm{R} 13$ for $\alpha v \beta 3$ receptor, $\alpha v \beta 3$-positive cells (Hela cells and B16 cells) and $\alpha v \beta 3$-negative cells (MCF-7 cells) were chosen to perform comparative experiments. Hela cells, B16 cells, and MCF-7 cells were incubated with FITC-R13 and then analyzed using flow cytometry. As is shown in Figure 1, the percentage of positive Hela cells and $\mathrm{B} 16$ cells is much higher than that of MCF-7 cells. The results indicate that $\mathrm{R} 13$ showed specificity for $\alpha v \beta 3$-positive cells in vitro and in Hela cells and B16 cells.

\section{Synthesis and characterization of PI 23-PEI-RI 3}

The degradable PEI derivates of P123-PEI were synthesized by linking PEI $2 \mathrm{kDa}$ with P123 and then conjugated with a bifunctional peptide R13 to prepare a new nonviral gene delivery vector P123-PEI-R13 (Figure 2). As for P123PEI, the free hydroxyl groups of P123 were activated by succinimidyl carbonate in advance and then linked to the amino groups of PEI. ${ }^{21}$ SMCC was used as crosslinker to conjugate P123-PEI with R13. The structures of P123-PEI and P123-PEI-R13 were confirmed by ${ }^{1} \mathrm{H}$ NMR spectroscopy (Figure 3). Figure 3A shows the ${ }^{1} \mathrm{H}-\mathrm{NMR}$ spectra of P123-PEI in $\mathrm{D}_{2} \mathrm{O}$, where $-\mathrm{CH}_{2} \mathrm{CH}_{2} \mathrm{O}$ - proton peaks appear at $\delta 3.55 \mathrm{ppm}$ and $-\mathrm{CH}_{2} \mathrm{CH}_{2} \mathrm{NH}$ - proton peaks appear at $\delta 2.51-2.7 \mathrm{ppm}$. Figure $3 \mathrm{~B}$ shows the ${ }^{1} \mathrm{H}-\mathrm{NMR}$ spectra of P123-PEI-R13 in $\mathrm{D}_{2} \mathrm{O}$, where the proton peaks move toward the lower magnet field as compared with those in Figure $3 \mathrm{~A}$, due to the 


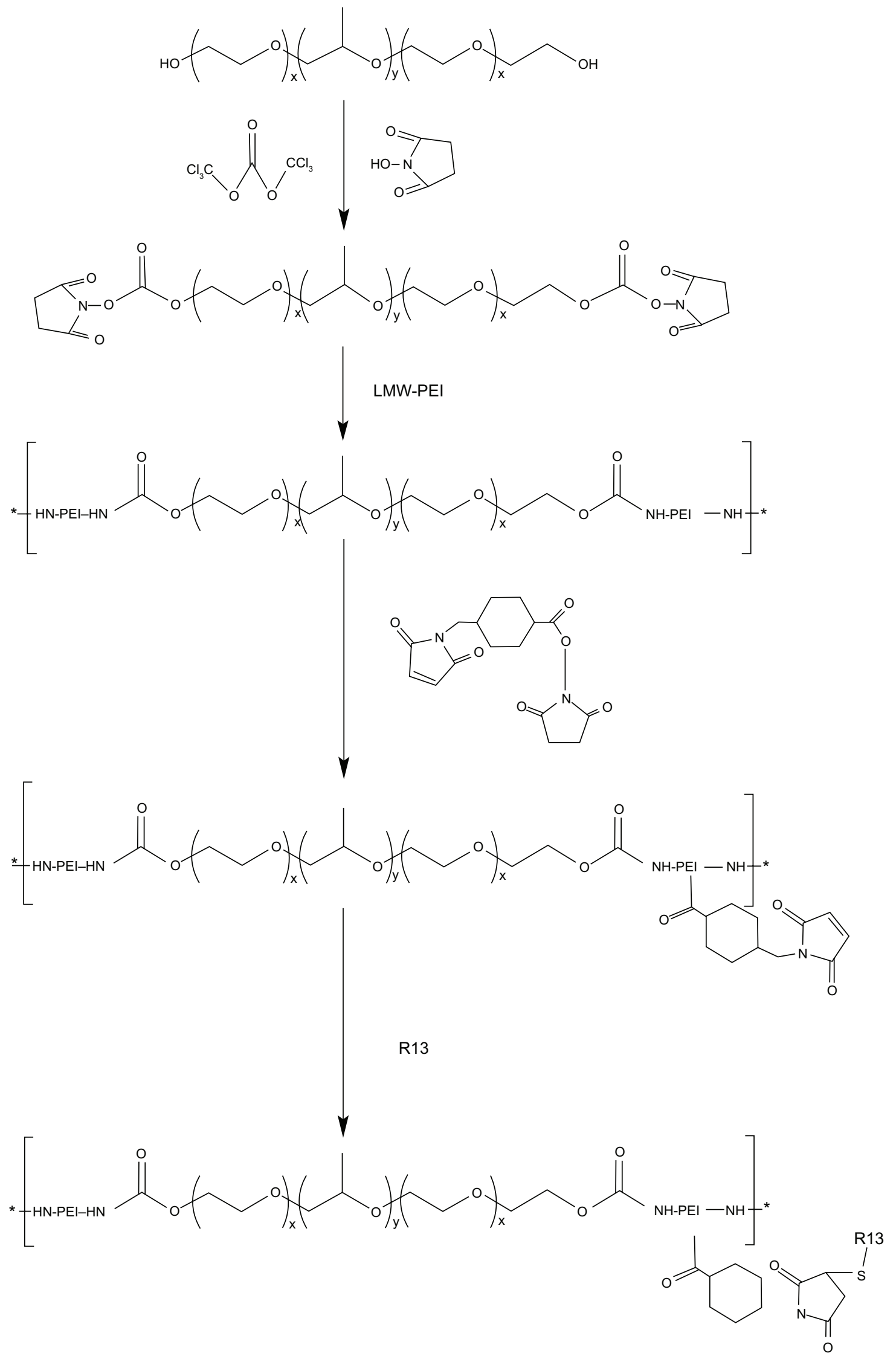

Figure 2 Synthetic scheme of PI23-PEI-RI3.

Abbreviation: LMW-PEI, low-molecular-weight polyethylenimine. 


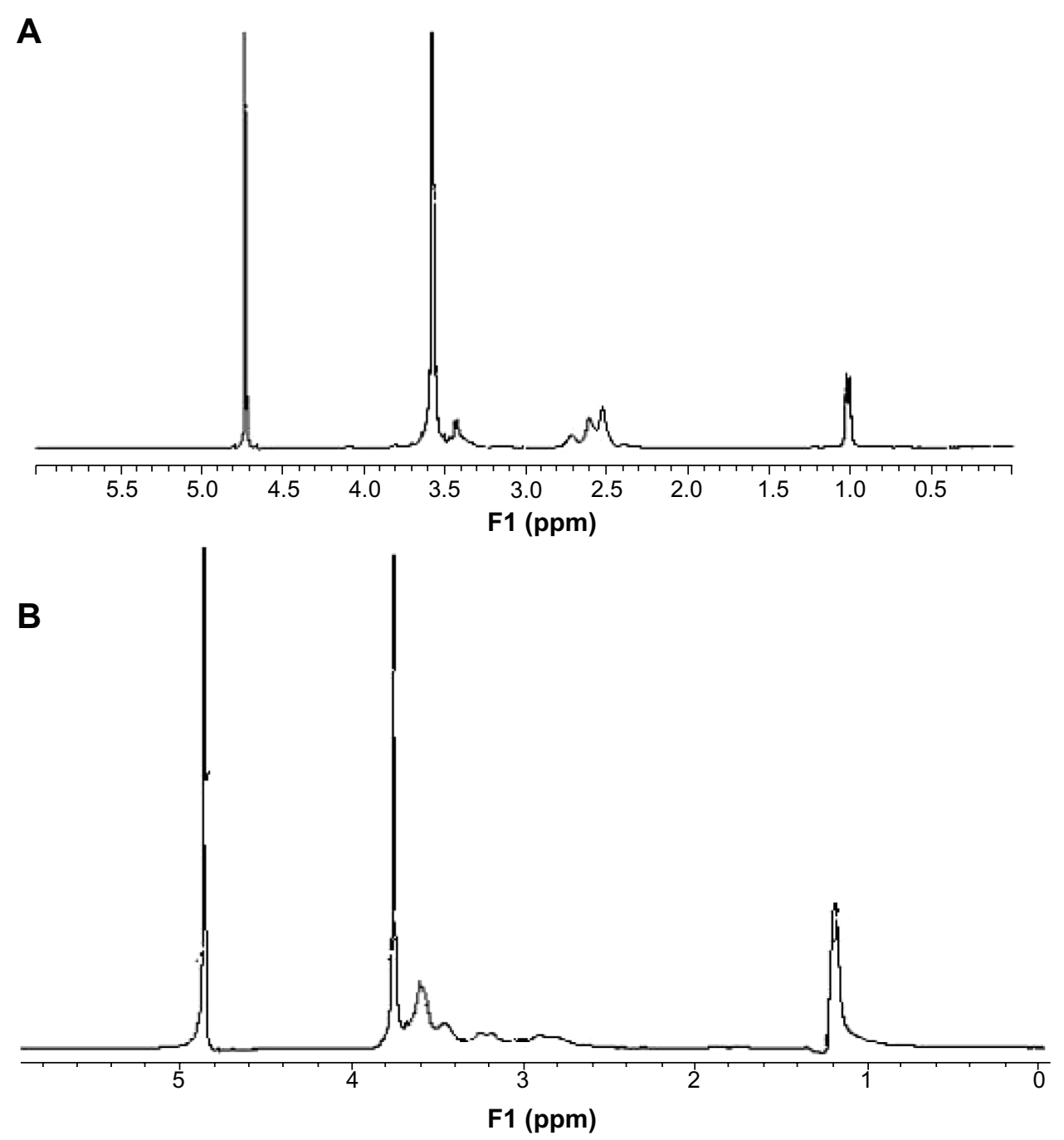

Figure 3 ' $\mathrm{H}$ - nuclear magnetic resonance spectra of PI23-polyethylenimine (PEI) (A) and PI23-polyethylenimine-RI3 (B) in deuterium oxide at room temperature.

production of groups with electronic screening effect from R13, such as the amide group and carbonyl group. At the same time, the proton peaks at $\delta 2.51-2.7 \mathrm{ppm}$ applanatus, and the peak value at $\delta 1.00 \mathrm{ppm}$ increases, indicating that R13 has been coupled to P123-PEI successfully.

\section{Degradation studies}

After a nondegradable carrier (eg, PEI $25 \mathrm{kDa}$ ) transfers pDNA into target cells, it cannot be degraded or eliminated from the cells. The intracellular accumulation leads to potential cytotoxicity. So degradation of gene-delivery polymers in vivo is very important for safe gene transfection. ${ }^{22,23}$ The ester bonds of the synthetic P123-PEI-R13 are susceptible to hydrolysis at physiological conditions so that the polymer can degrade into poloxamer oligomers and LMW PEI, which can be secreted to the extracellular environment by exocytosis, and shows little toxic effect on cells. The average results of the test for in vitro degradation are shown in Figure 4 with standard deviation bars. P123-PEI-R13 was degraded slowly and the degradation was nearly completed after about 60 hours.

In order to obtain meaningful information for the degradation model, the degradation profile was fitted to three different kinetic models, and the goodness of fit of the degradation data was assessed. The degradation profile of P123-PEI-R13 could be well described by a zero-order model. The half-life of P123-PEI-R13 was found to be about 30 hours, according to the model.

\section{Particle size and zeta potential measurements}

The particle size and zeta potential of polymer/DNA complexes were examined at different $\mathrm{w} / \mathrm{w}$ ratios. As is shown in Figure 5, with an increase of polymer/DNA weight ratios the particle size decreased. This showed that the polymers with more charge could condense DNA more effectively. All polymers can concentrate pDNA into nanoparticles, and 


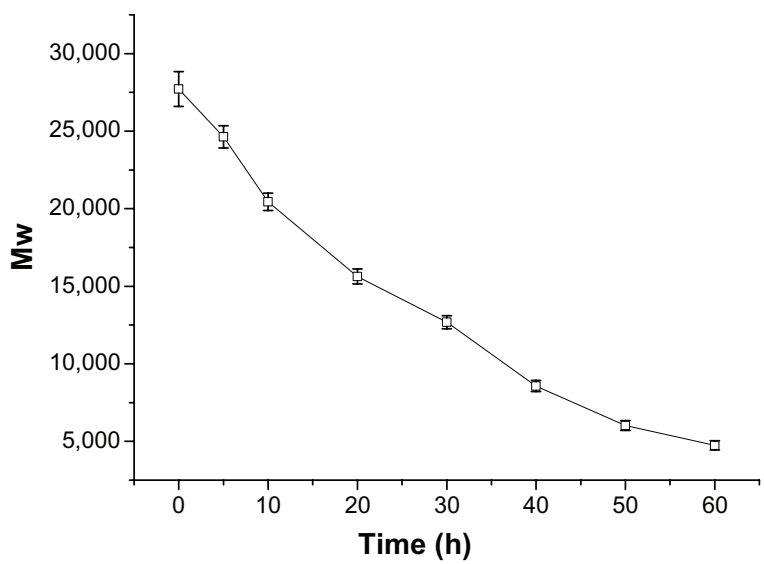

Figure 4 Degradation of PI23-polyethylenimine-RI3. The polymers were dissolved in $0.1 \mathrm{M}$ phosphate-buffered saline $(\mathrm{pH}=7.4)$ and incubated at $37^{\circ} \mathrm{C}$ and 100 $\mathrm{rpm}$. Determination of molecular weight (MW) was measured by gel permeation chromatography with multiangle laser light scattering $(n=3)$.

their average particle sizes vary from $100 \mathrm{~nm}$ to $250 \mathrm{~nm}$, depending on the composition of the complexes, which are suitable for efficient gene delivery in vivo. ${ }^{24}$ In the range of concentration studied, no precipitation was observed at any $\mathrm{w} / \mathrm{w}$ ratios.

Positively charged surfaces of the complexes are thought to be important for binding to negatively charged cellular membranes and cellular uptake via endocytosis. ${ }^{25}$ However, strong cationic charges of the complexes also lead to cytotoxicity. ${ }^{21}$ Figure 6 shows zeta potentials of the complexes according to $\mathrm{w} / \mathrm{w}$ ratio. The zeta potentials of all complexes were gradually increased in accordance with the increase of charge ratios. At low w/w ratios, the zeta potential of the

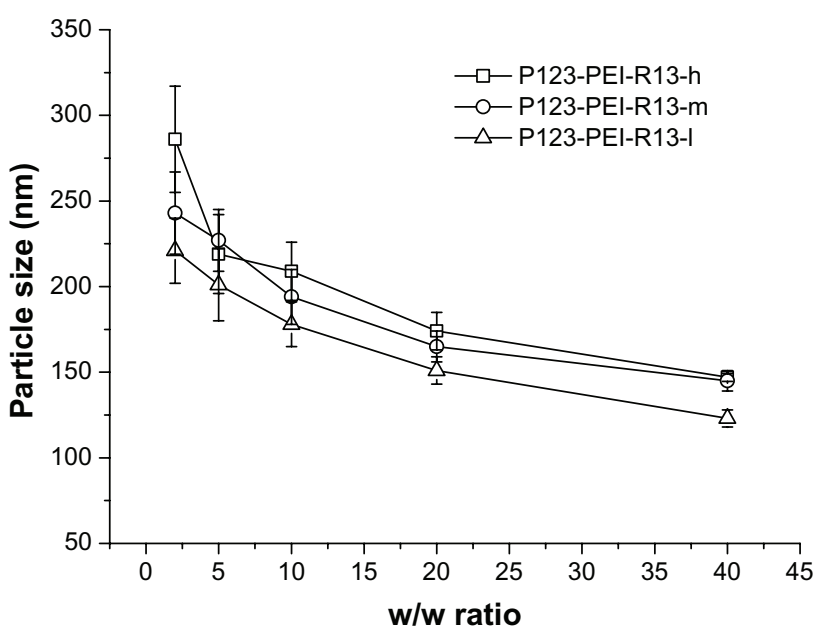

Figure 5 Particle sizes (nm) of PI23-polyethylenimine (PEI)-RI3/DNA complexes at various $\mathrm{w} / \mathrm{w}$ ratios.

Note: The data were expressed as mean values ( \pm standard deviations, $n=3$ ).

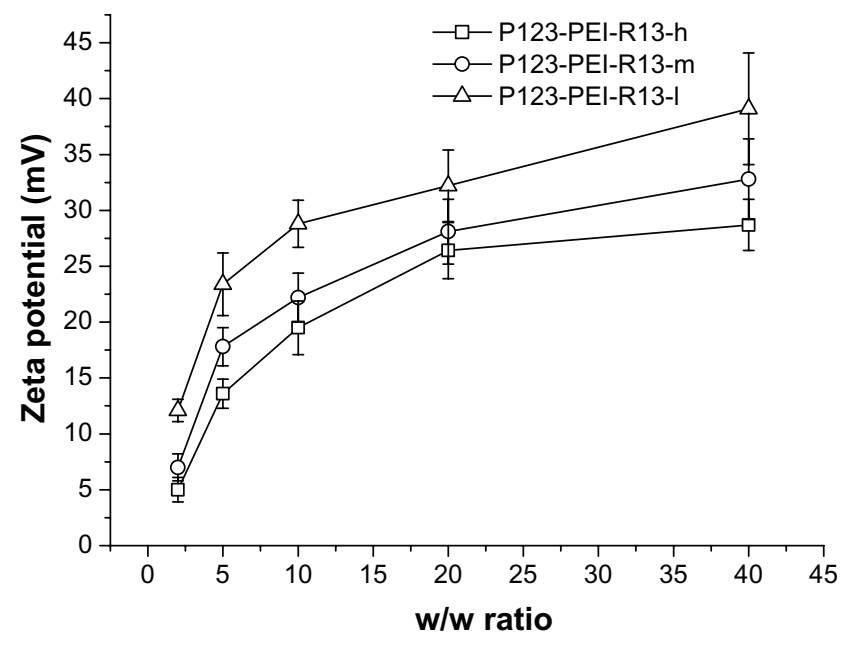

Figure 6 Zeta potential $(\mathrm{mV})$ of PI23-polyethylenimine (PEI)-RI3/DNA complexes at various $\mathrm{w} / \mathrm{w}$ ratios.

Note: The data were expressed as mean values ( \pm standard deviations, $n=3$ ).

complexes was a slightly positive value. The zeta potentials rapidly increased up to $\mathrm{w} / \mathrm{w}$ ratio 10 , whereas they slowly increased from $\mathrm{w} / \mathrm{w}$ ratio 10 .

\section{Condensation status of plasmid DNA by PI23-PEI-RI3}

The DNA condensation capacity of P123-PEI-R13 was determined by gel retardation experiments at various $\mathrm{w} / \mathrm{W}$ ratios. As is shown in Figure 7, the movement of the plasmid DNA in the gel is retarded as the amount of the polymers increases, demonstrating that the polymers bind to the DNA and neutralize its charge. When the w/w ratios of the polymer and DNA exceed the neutralization composition, the complexes will have a positive charge and stop migrating toward the anode. In this experiment, all the polymers of P123-PEIR13 were able to condense DNA effectively and neutralized its charge at a w/w ratio of 2 . Moreover, for unconjugated P123-PEI, DNA was retarded at a w/w ratio of 0.4 (data not shown). Correspondingly, more P123-PEI-R13 was needed to condense pDNA completely than P123-PEI, possibly because more primary amines of P123-PEI were substituted by R13 so that less positively charged primary amines interacted with negatively charged pDNA phosphates. ${ }^{24}$

\section{Protection of PI23-PEI-RI 3 on plasmid DNA}

After the complex solution was incubated with DNase I, partial DNA was still protected from digestion by DNase I, even at a concentration of $6 \mathrm{U}$ DNase I/ $\mu \mathrm{g}$ DNA, and was released from the complex (Figure 8A). In fact, under the same experimental conditions, DNA could be completely 
A

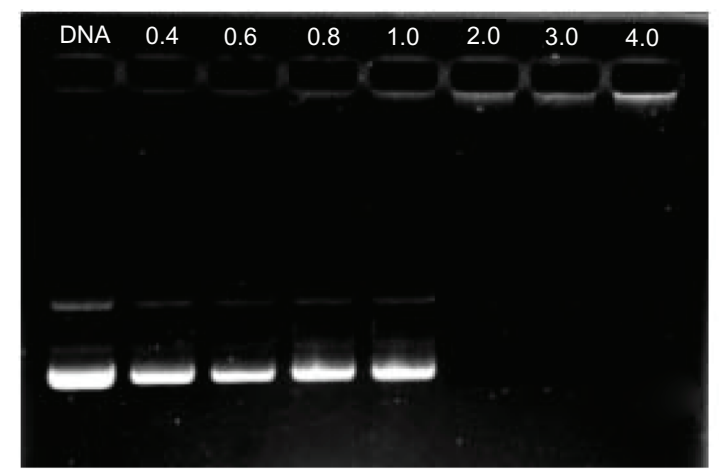

B

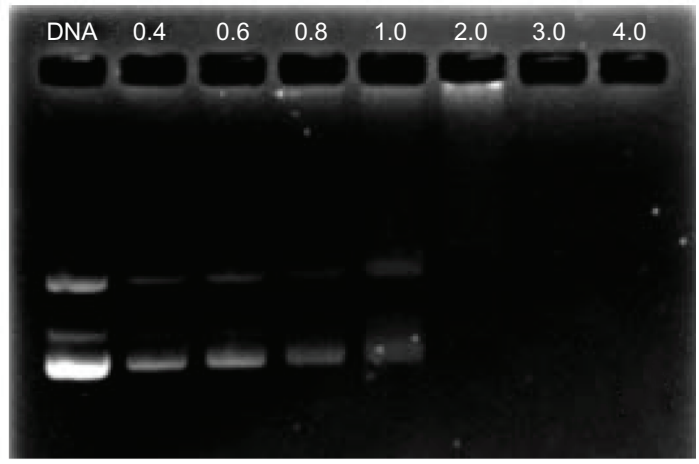

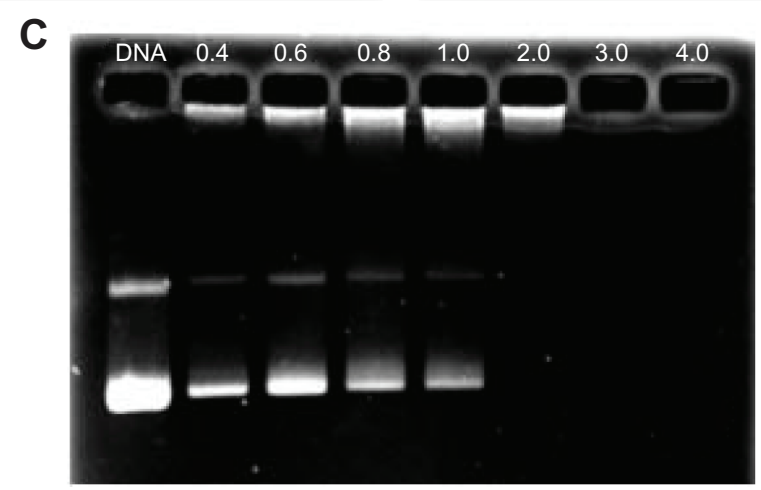

Figure 7 Agarose gel electrophoresis of the complexes at various w/w (PI23-polyethylenimine [PEI]-RI3/DNA) ratios: (A) PI23-PEI-RI3-h, (B) PI23-PEI-RI3-m, and (C) PI23-PEI-RI3-I.

digested by DNase I at a concentration of $0.08 \mathrm{U}$ DNase $\mathrm{I} / \mu \mathrm{g}$ DNA. ${ }^{26}$

The stability evaluation of the P123-PEI-R13/DNA complex in vivo was simulated by treating the complex with serum and sodium heparin in vitro. As is shown in Figure 8B, serum cannot dissociate the complex even at a concentration of 50\%. To infer, the P123-PEI-R13/DNA complex may remain stable in blood circulation.

Sodium heparin with a potent negative charge can be used to simulate macromolecules carrying negative charges in the blood and evaluate the antidissociation ability of a vector system in vitro. Sodium heparin can dissociate the complexes in a concentration-dependent manner. ${ }^{26}$ Sodium heparin could dissociate the P123-PEI-R13/DNA complexes when its concentration was $260 \mu \mathrm{g} / \mathrm{mL}$ at a w/w ratio of 20:1. The concentration of sodium heparin was more than $600 \mu \mathrm{g} / \mathrm{mL}$ before complete dissociation of the complexes (Figure 8C).

\section{Cytotoxicity assay}

There was a correlation between cytotoxicity and molecular weight. The high-molecular-weight PEI was limited as a transfection reagent for its relatively high cytotoxicity.
Many attempts were made to reduce the cytotoxicity of the gene carrier, of which the most favorable one is an introduction of degradable polymer through some linkers. $^{23,27-29}$ Here, the cytotoxicity of the degradable P123PEI-R13 was evaluated in Hela cells and B16 cells using the MTT assay in comparison with PEI $25 \mathrm{kDa}$. As is shown in Figures 9 and 10, P123-PEI-R13 and PEI 2 KDa showed significantly higher cell viability as compared with PEI $25 \mathrm{kDa}$ at any concentration $(P<0.01)$. It is worthwhile noting that P123-PEI-R13 showed low cytotoxicity at various concentrations, even at a high concentration, indicating that the polymer is very suitable for gene delivery because we can administrate more P123-PEI-R13 to improve transfection efficiency if necessary.

The lower cytotoxicity may be due to the lower amino group density and low toxic building blocks. ${ }^{9,22}$ As far as P123-PEI-R13 is concerned, the ester bonds of the polymer can degrade into poloxamer oligomers and LMW PEI at physiological conditions, which can be rapidly excluded from the cell, then show little cytotoxicity. Meanwhile, the amino group density compared with high-molecular-weight PEI may also be reduced, resulting in lower cytotoxicity to the cells. 
A

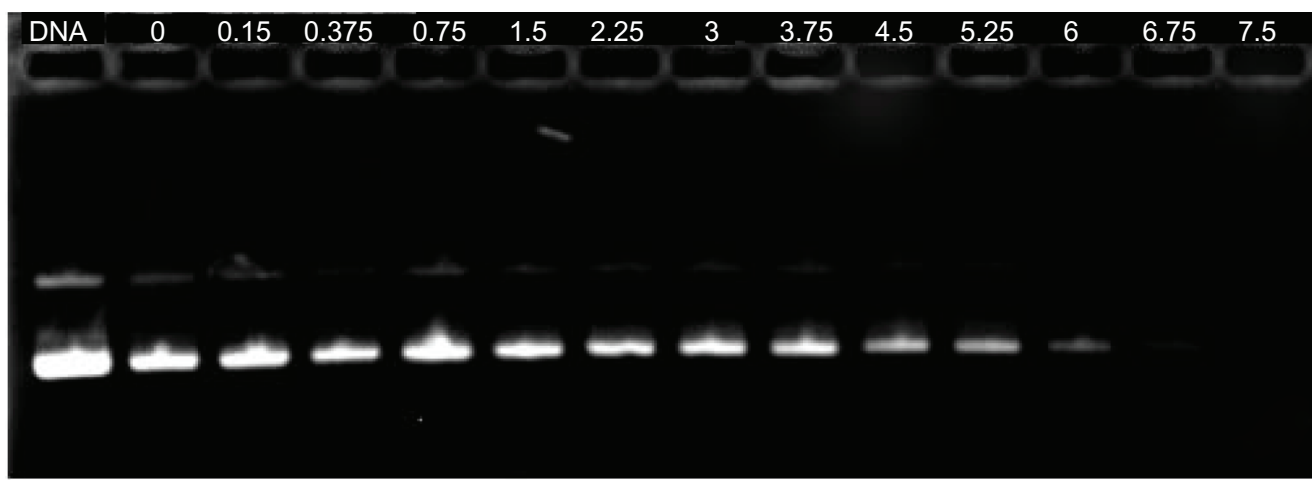

B

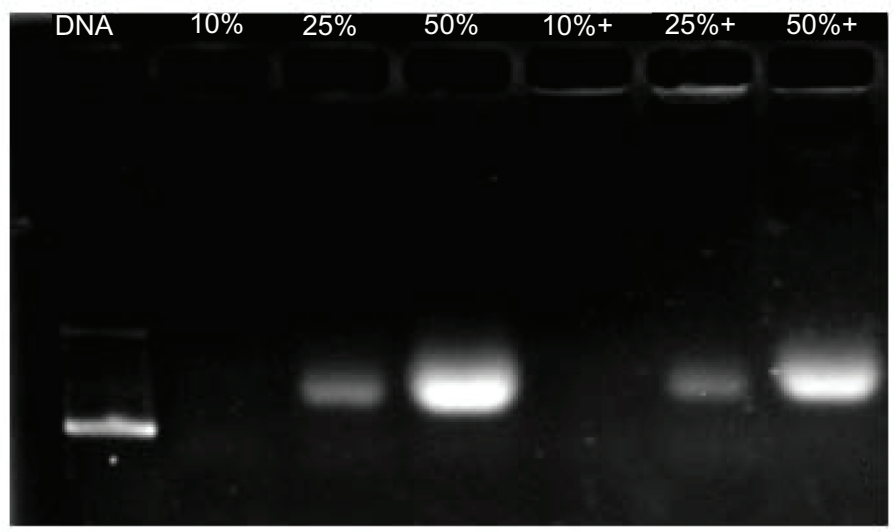

C

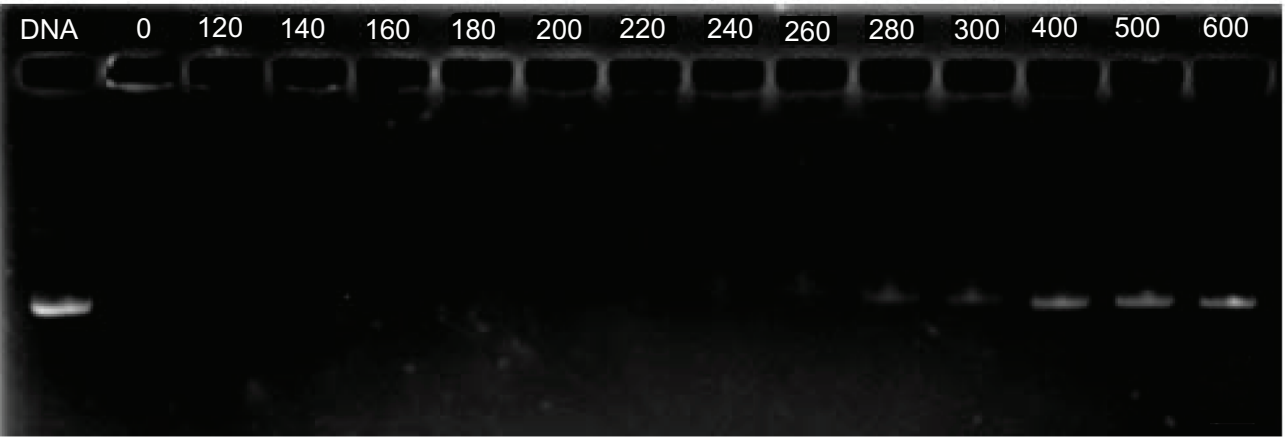

Figure 8 Protection of PI23-polyethylenimine (PEI)-RI3 on plasmid DNA. (A) Protection of plasmid DNA from degradation by DNase I at varying concentrations of 0

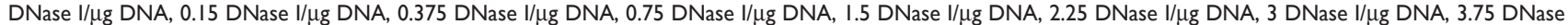

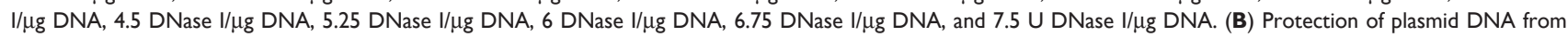
dissociation by serum at varying concentrations of $10 \%, 25 \%$, and $50 \%$. The lanes $10 \%, 25 \%$, and $50 \%$ without "+" refer to the presence of only $10 \%, 25 \%$, and $50 \%$ serum. The lanes 10\%, 25\%, and 50\% with "+" refer to the presence of PI23-PEI-RI3/DNA complexes at w/w ratio 20 with different concentration of serum. (C) Protection of plasmid DNA from dissociation by sodium heparin at varying concentrations of $0 \mu \mathrm{g} / \mathrm{mL}, 120 \mu \mathrm{g} / \mathrm{mL}, 140 \mu \mathrm{g} / \mathrm{mL}, 160 \mu \mathrm{g} / \mathrm{mL}, 180 \mu \mathrm{g} / \mathrm{mL}, 200 \mu \mathrm{g} / \mathrm{mL}, 220 \mu \mathrm{g} / \mathrm{mL}, 240 \mu \mathrm{g} / \mathrm{mL}$, $260 \mu \mathrm{g} / \mathrm{mL}, 280 \mu \mathrm{g} / \mathrm{mL}, 300 \mu \mathrm{g} / \mathrm{mL}, 400 \mu \mathrm{g} / \mathrm{mL}, 500 \mu \mathrm{g} / \mathrm{mL}$, and $600 \mu \mathrm{g} / \mathrm{mL}$.

\section{In vitro transfection efficiency}

As for the pEGFP-N2 reporter gene, transfection efficiency of P123-PEI-R13 polymers in Hela and B16 cells is shown in Figure 11A and B. In Figure 11A and B, transfection efficiency of P123-PEI-R13/DNA complexes increased in correlation with the w/w ratio in Hela cells and B16 cells. On the whole, the EGFP reporter gene expression in Hela cells exceeded that in B16 cells, showing that the gene transfection was selective to cells. Representative fluorescence images for the transfection of Hela cells and B16 cells using P123PEI-R13 at the optimal conditions are shown in Figure 11C. The microscopic images in a bright field of nontransfected cells and transfected cells are included in Figure 11D. The transfection of P123-PEI-R13/DNA complexes did not alter the morphology of the cells, indicating that P123-PEI-R13 was suitable for gene delivery.

Figure 12 shows the results of the gene transfection efficiency of P123-PEI-R13/pGL3-control complexes in 


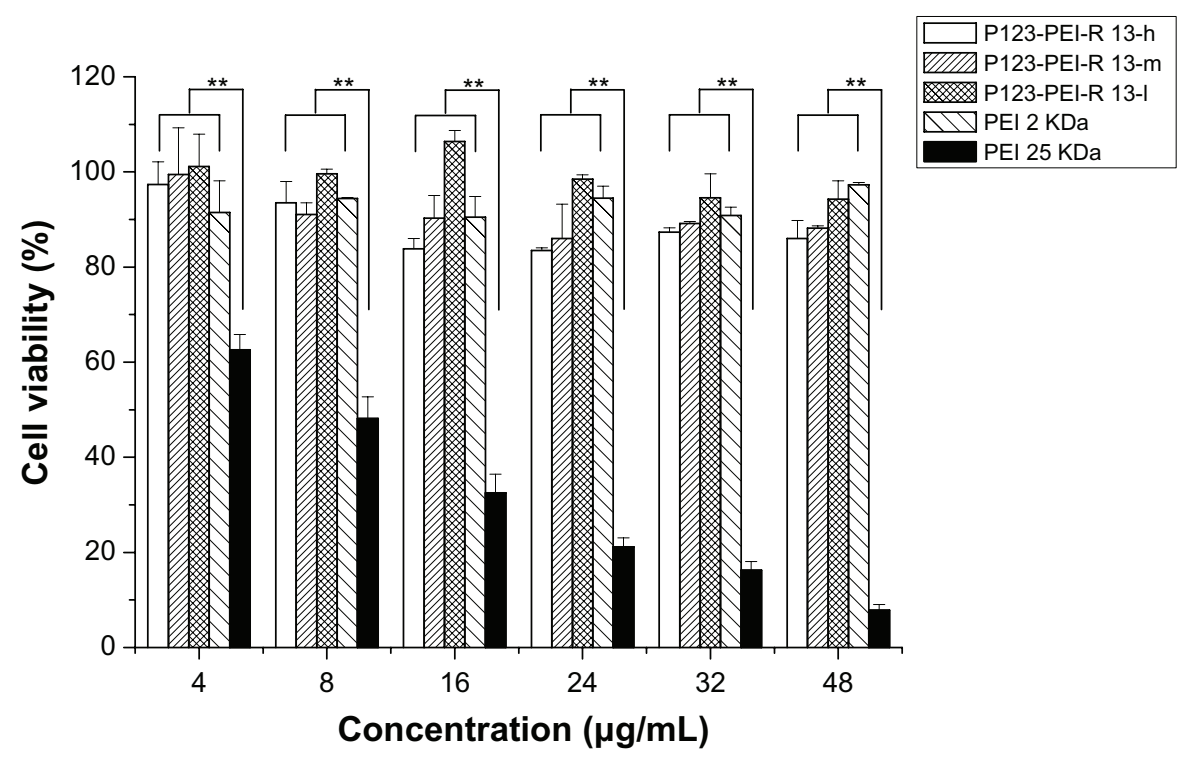

Figure 9 Cytotoxicity of PI23-polyethylenimine (PEI)-RI3 at various concentrations in Hela cell lines using the 3-(4, 5-dimethylthiazol-2-yl)-2, 5-diphenyl tetrazolium bromide assay. Notes: Each data point represents the mean \pm standard deviation. $n=6, * * p<0.01$.

Hela cells in comparison with P123-PEI and PEI 2 KDa polyplexes. The P123-PEI-R13-h, P123-PEI-R13-m, and P123-PEI-R13-1 polyplexes exhibited the maximal transfection efficiency at the weight ratio of 30 . Based on cytotoxicity assay, the cell viability was over $85 \%$ at the w/w (polymer/ DNA) ratio of 30 . All synthesized P123-PEI-R13 showed much higher gene transfer ability compared with PEI 2 KDa, and the highest luciferase expression level obtained at P123PEI-R13-1 was more than 230 times higher compared with that of PEI $2 \mathrm{KDa}$, and even about two times higher than PEI
$25 \mathrm{KDa}$ at the optimal conditions ( $\mathrm{w} / \mathrm{w}=0.8$, data not shown). It should be noted that the bifunctional R13 peptide not only could make the P123-PEI-R13/DNA complexes target the cells but also could promote cargo transport. Therefore, the P123-PEI-R13/DNA complexes showed about 34 times higher gene transfection than P123-PEI/DNA complexes at optimal conditions. In addition, transfection efficiency of P123-PEI-R13 decreased with an increase of the R13 rate, which can be explained by the high modification degree of R13 leading to a less positive surface. Figure 13 shows the

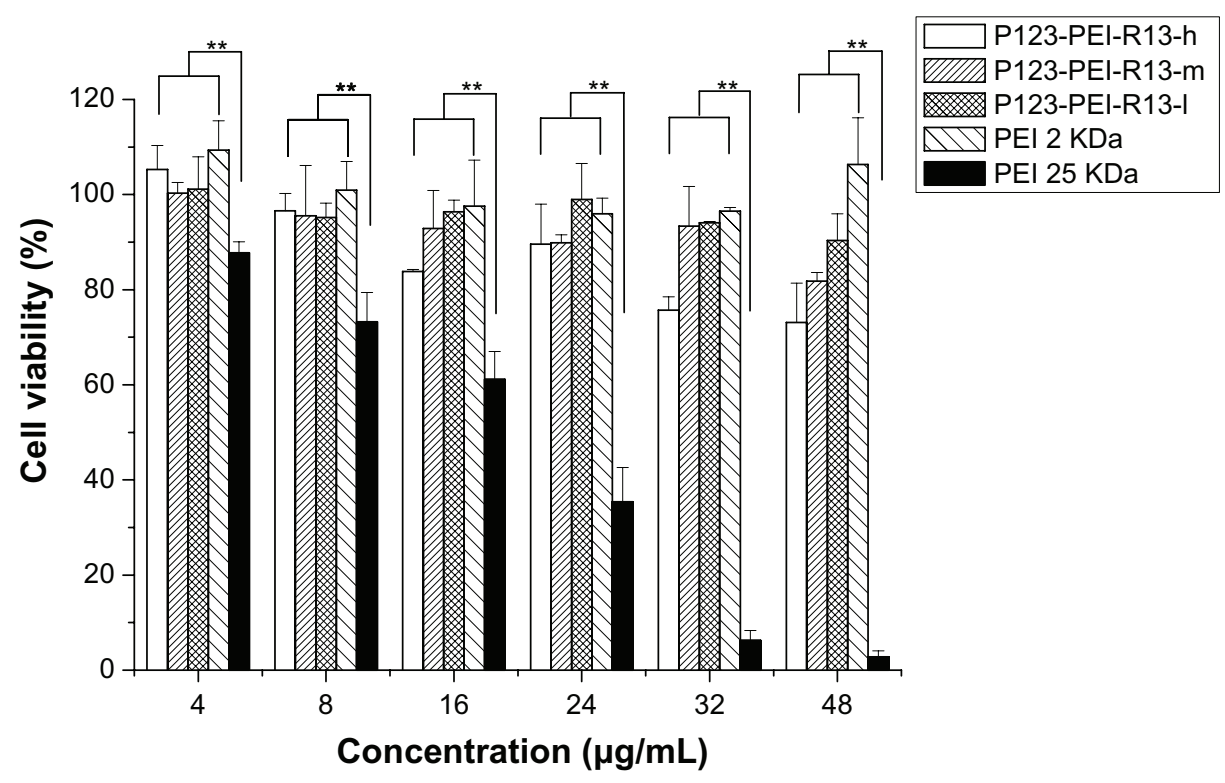

Figure 10 Cytotoxicity of PI23-polyethylenimine (PEI)-RI3 at various concentrations in BI6 cell lines using the 3-(4, 5-dimethylthiazol-2-yl)-2, 5-diphenyl tetrazolium bromide assay.

Notes: Each data point represents the mean \pm standard deviation; $n=6, * * p<0.01$. 
A
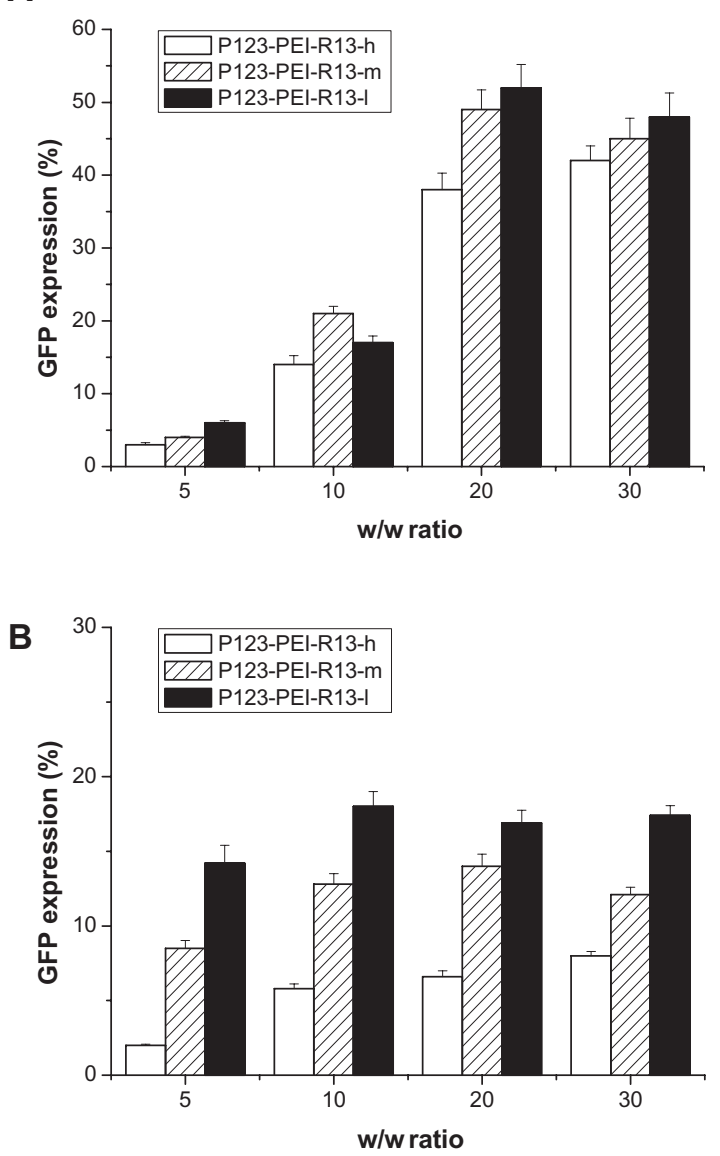

C

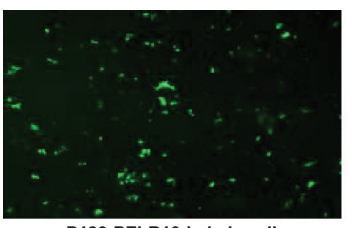

P123-PEI-R13-h, hela cells

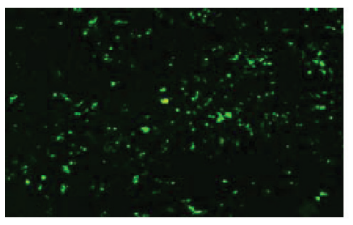

P123-PEI-R13-m, hela cells

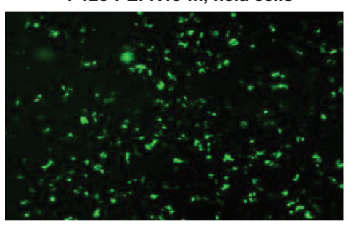

P123-PEI-R13-I, hela cells

D

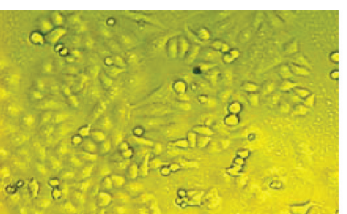

Non-transfected hela cells

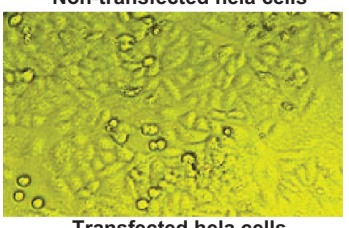

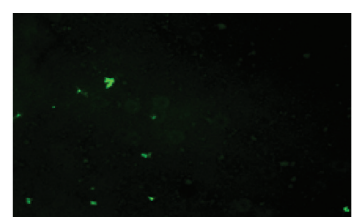

P123-PEI-R13-h, B16 cells

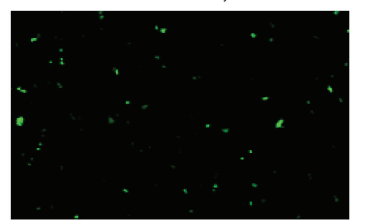

P123-PEI-R13-m, B16 cells

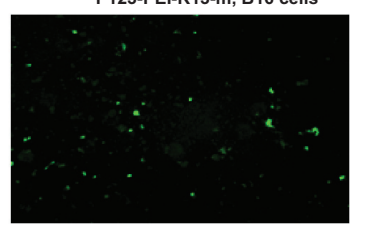

P123-PEI-R13-I, B16 cells

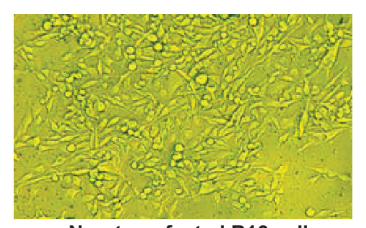

Non-transfected B16 cells

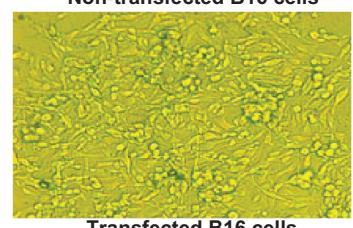

Figure I I Green fluorescent protein (GFP) reporter gene transfection in Hela cells and BI6 cells by PI23-polyethylenimine (PEI)-R I3. (A) Percentage of GFP transfection in Hela cells by flow cytometry analysis (the mean \pm standard deviation, $n=3$ ). (B) Percentage of GFP transfection in BI6 cells by flow cytometry analysis (the mean \pm standard deviation, $n=6$ ). (C) Representative fluorescence images for the transfection of Hela cells and BI6 cells using PI23-PEI-RI3 at optimal conditions. (D) Microscopic images in bright field of nontransfected cells and transfected cells.

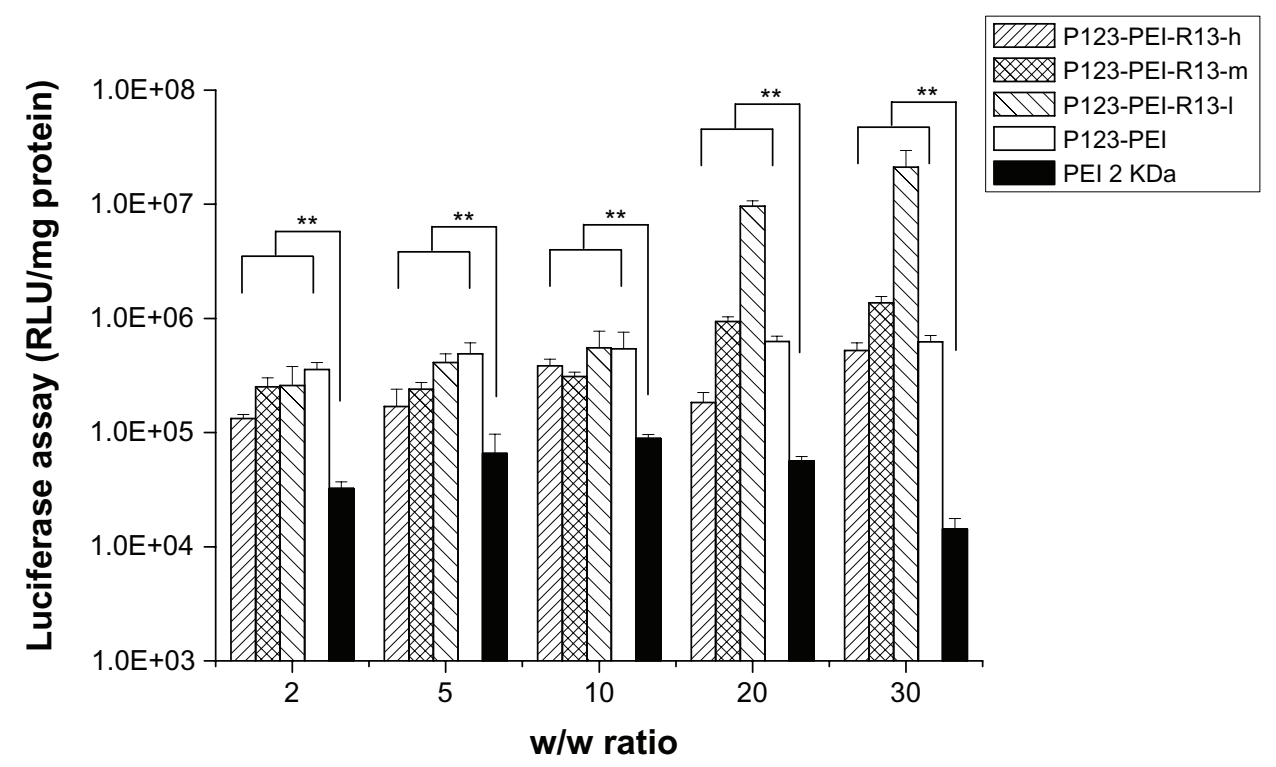

Figure 12 Transfection efficiency of different polymer/DNA complexes at Hela cell line.

Notes: Each data point represents the mean \pm standard deviation; $n=6$, $* * P<0.01$.

Abbreviations: PEI, polyethylenimine; RLU, relative light unit. 


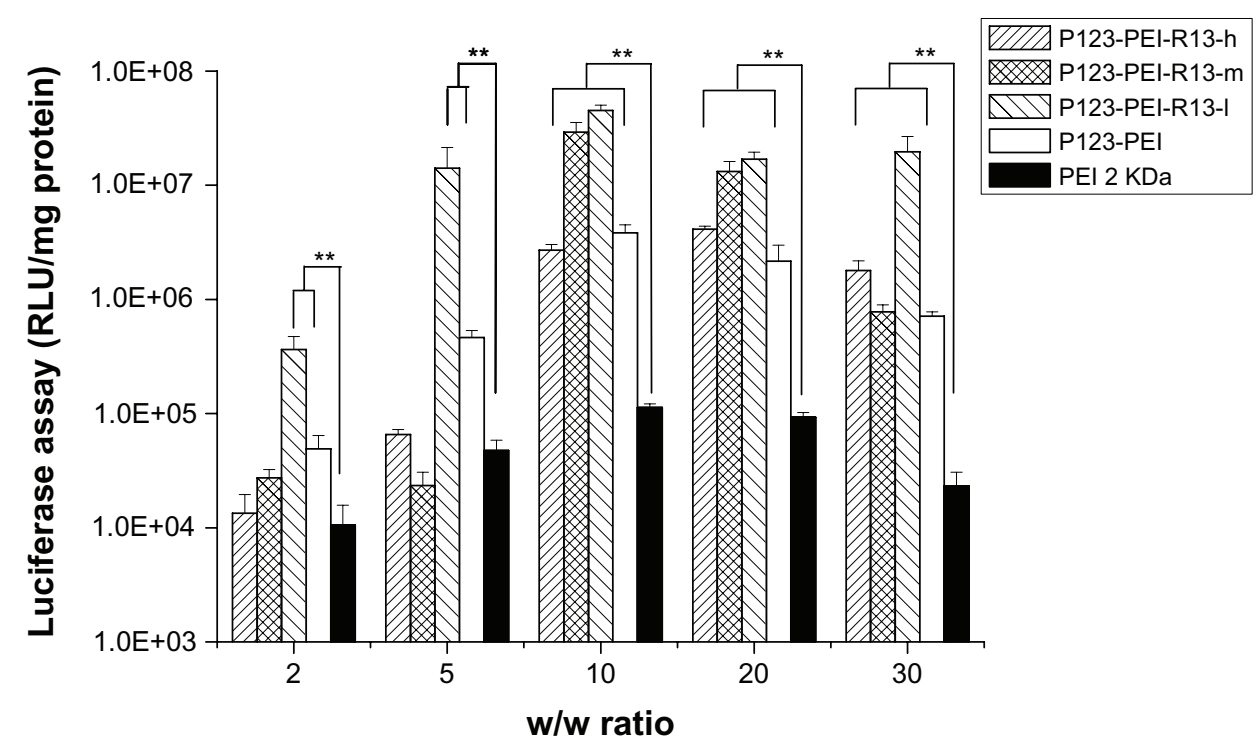

Figure 13 Transfection efficiency of different polymer/DNA complexes at BI6 cell line. Notes: Each data point represents the mean \pm standard deviation; $\mathrm{n}=6, * * p<0.0$ I. Abbreviations: PEl, polyethylenimine; RLU, relative light unit.

results of the gene transfection efficiency of P123-PEI-R13/ pGL3-control complexes in B16 cells in comparison with P123-PEI and PEI 2 KDa polyplexes. The P123-PEI-R13-h, P123-PEI-R13-m, and P123-PEI-R13-1 polyplexes exhibited the maximal transfection efficiency at the weight ratio of 20 , 10 , and 10, respectively. Accordingly, the cell viabilities were $75.73 \% \pm 2.81 \%, 92.84 \% \pm 8.06 \%$, and $96.40 \% \pm 2.41 \%$, based on cytotoxicity assay. Similar to the transfection of P123-PEI-R13 polyplexes in Hela cells, they also showed much higher gene transfection than P123-PEI, PEI 2 KDa, and PEI $25 \mathrm{KDa}$ polyplexes at optimal conditions.

\section{Conclusion}

We developed a new nonviral gene vector, PEI-P123-R13, by crosslinking LMW PEI with P123 and further coupled a bifunctional peptide R13 to the polymer for targeting tumor and increasing cellular uptake. Through various physicochemical methods, we confirmed that PEI-P123-R13 had the ability to form complexes with DNA and suitable physicochemical properties for gene delivery. Furthermore, the new gene vector showed much lower cytotoxicity and higher gene transfection efficiency compared with PEI $25 \mathrm{kDa}$ in two different cell lines (Hela and B16). In conclusion, this new polymer might be a potential candidate in gene delivery with low cytotoxicity and high transfection efficiency. However, it is worth investigating whether PEI-P123-R13 can exhibit the same excellent properties such as cyclical stability, tumor targeting, noncytotoxicity, and effective transfection in vivo. Also, the delivery of therapeutic genes mediated by this gene vector and the therapeutic efficiency need to be studied in animal models. We are currently conducting more comprehensive studies with the aim to answer these questions. We will present our findings in another manuscript.

\section{Acknowledgment}

This study was supported by the National Natural Science Foundation, People's Republic of China (81001024), and the Leading Academic Discipline Project of Shanghai Municipal Education Commission (J50704).

\section{Disclosure}

The authors report no conflicts of interest in this work.

\section{References}

1. Morille M, Passirani C, Vonarbourg A, Clavreul A, Benoit JP. Progress in developing cationic vectors for non-viral systemic gene therapy against cancer. Biomaterials. 2008;29:3477-3496.

2. Wu X, Ding B, Gao J, et al. Second-generation aptamer-conjugated PSMA-targeted delivery system for prostate cancer therapy. Int J Nanomedicine. 2011;6:1747-1756.

3. Cho KC, Choi SH, Park TG. Low molecular weight PEI conjugated pluronic copolymer: useful additive for enhancing gene transfection efficiency. Macromolecular Research. 2006;14(3)348-353.

4. Lee K, Bae KH, Lee Y, Lee SH, Ahn CH, Park TG. Pluronic/polyethylenimine shell crosslinked nanocapsules with embedded magnetite nanocrystals for magnetically triggered delivery of siRNA. Macromol Biosci. 2010;10(3):239-245.

5. Lungwitz U, Breunig M, Blunk T, Göpferich A. Polyethylenimine-based non-viral gene delivery systems. Eur J Pharm Biopharm. 2005;60: 247-266.

6. Liu T, Yu X, Kan B, Guo Q, Wang X, Shi S, et al. Enhanced gene delivery using biodegradable poly(ester amine)s (PEAs) based on low-molecularweight polyethylenimine and poly(epsilon-caprolactone)-pluronicpoly(epsilon-caprolactone). J Biomed Nanotechnol. 2010;6(4):351-359. 
7. Neu M, Fischer D, Kissel T. Recent advances in rational gene transfer vector design based on poly (ethylene imine) and its derivatives. J Gene Med. 2005;7:992-1009.

8. Deng R, Yue Y, Ji F, Chen Y, Kung H-F, Lin MCM, et al. Revisit the complexation of PEI and DNA-how to make low cytotoxic and highly efficient PEI gene transfection non-viral vectors with a controllable chain length and structure? J Control Release. 2009; 140:40-46.

9. Huang H, Yu H, Tang G, Wang Q, Li J. Low molecular weight polyethylenimine cross-linked by 2-hydroxypropyl-gamma-cyclodextrin coupled to peptide targeting HER2 as a gene delivery vector. Biomaterials. 2010;31:1830-1838.

10. Kabanov AV, Lemieux P, Vinogradov S, Alakhov V. Pluronic block copolymers: novel functional molecules for gene therapy. Adv Drug Deliv Rev. 2002;54:223-233.

11. Guo Q, Shi S, Wang X, Kan B, Gu Y, Shi X, et al. Synthesis of a novel biodegradable poly(ester amine) (PEAs) copolymer based on low-molecular-weight polyethyleneimine for gene delivery. Int J Pharm. 2009;379(1):82-89.

12. KoYT, Kale A, Hartner WC, Papahadjopoulos-Sternberg B, Torchilin VP. Self-assembling micelle-like nanoparticles based on phospholipidpolyethyleneimine conjugates for systemic gene delivery. J Control Release. 2009;133(2):132-138.

13. Kabanov AV, Batrakova EV, Sriadibhatla S, Yang Z, Kelly DL, Alakov VY. Polymer genomics: shifting the gene and drug delivery paradigms. J Control Release. 2005;101:259-271.

14. Sahay G, Batrakova EV, Kabanov AV. Different internalization pathways of polymeric micelles and unimers and their effects on vesicular transport. Bioconjug Chem. 2008;19:2023-2029.

15. Choo ESG, Yu B, Xue JM. Synthesis of poly(acrylic acid) (PAA) modified pluronic P123 copolymers for pH-stimulated release of doxorubicin. J Colloid Interf Sci. 2011;358:462-470.

16. Ogawa M, Hatano K, Oishi S, et al. Direct electrophilic radiofluorination of a cyclic RGD peptide for in vivo $\alpha v \beta 3$ integrin related tumor imaging. Nucl Med Biol. 2003;30:1-9.

17. Lee DE, Hong YD, Choi KH, Lee S-Y, Park PH, Choi SJ. Preparation and evaluation of ${ }^{99 \mathrm{~m}} \mathrm{Tc}-$ labeled cyclic arginine-glycine-aspartate (RGD) peptide for integrin targeting. Appl Radiat Isotopes. 2010;68: 1896-1902.
18. Kilk K, El-Andaloussi S, Järver P, et al. Evaluation of transportan 10 in PEI mediated plasmid delivery assay. J Control Release. 2005;103: 511-523.

19. Santos-Cuevas CL, Ferro-Flores G, Murphy CA, et al. Design, preparation, in vitro and in vivo evaluation of ${ }^{99 \mathrm{~m}} \mathrm{Tc}-\mathrm{N} 2 \mathrm{~S} 2-\mathrm{Tat}(49-57)-$ bombesin: a target-specific hybrid radiopharmaceutical. Int J Pharm. 2009;375:75-83.

20. Brooks H, Lebleu B, Vivés E. Tat peptide-mediated cellular delivery: back to basics. Adv Drug Deliv Rev. 2005;57:559-577.

21. Yin DF, Ding XY, Gao J, Chu C, Zou H, Gao S. Nonionic amphiphilic surfactant conjuncted polyethyleneimine as a new and highly efficient non-viral gene carrier. Macromol Res. 2009;17:19-25.

22. Kim TH, Cook SE, Arote RB, Cho MH, Nah JW, Choi YJ, Cho CS. A degradable hyperbranched poly(ester amine) based on poloxamer diacrylate and polyethylenimine as a gene carrier. Macromol Biosci. 2007;7:611-619.

23. Arote R, Kim TH, Kim YK, et al. A biodegradable poly(ester amine) based on polycaprolactone and polyethylenimine as a gene carrier. Biomaterials. 2007;28:735-744.

24. Ma K, Hu MX, Qi Y, et al. PAMAM-triamcinolone acetonide conjugate as a nucleus-targeting gene carrier for enhanced transfer activity. Biomaterials. 2009;30:6109-6118.

25. Kim T-I, Baek J-U, Yoon JK, Choi JS, Kim K, Park J-S. Synthesis and characterization of a novel arginine-grafted dendritic block copolymer for gene delivery and study of its cellular uptake pathway leading to transfection. Bioconjug Chem. 2007;18:309-317.

26. Hao JG, Sha XY, Tang YJ, et al. Enhanced transfection of polyplexes based on pluronic-polypropylenimine dendrimer for gene transfer. Arch Pharm Res. 2009;32:1045-1054.

27. Anderson DG, Akinc A, Hossain N, Langer R. Structure/property studies of polymeric gene delivery using a library of poly(b-amino esters). Mol Ther. 2005;11:426-434.

28. Lin C, Blaauboer CJ, Timoneda MM, et al. Engbersen, bioreducible poly(amido amine)s with oligoamine side chains: synthesis, characterization, and structural effects on gene delivery. J Control Release. 2008;126:166-174.

29. Park MR, Han KO, Cho MH, Nah JW, Choi YJ, Cho CS. Degradable polyethylenimine-alt-poly (ethylene glycol) copolymers as novel gene carriers. J Control Release. 2005;105:367-380.
International Journal of Nanomedicine

\section{Publish your work in this journal}

The International Journal of Nanomedicine is an international, peerreviewed journal focusing on the application of nanotechnology in diagnostics, therapeutics, and drug delivery systems throughout the biomedical field. This journal is indexed on PubMed Central, MedLine, CAS, SciSearch $\AA$, Current Contents ${ } /$ Clinical Medicine,

\section{Dovepress}

Journal Citation Reports/Science Edition, EMBase, Scopus and the Elsevier Bibliographic databases. The manuscript management system is completely online and includes a very quick and fair peer-review system, which is all easy to use. Visit http://www.dovepress.com/ testimonials.php to read real quotes from published authors. 